\title{
Microbial characterization and diversity of artisanal Ranchero cheese with emphasis in Lactococcus strains
}

\author{
Mario-Alejandro GALLEGOS-ACEVEDO ${ }^{1}$, América CHÁVEZ-MARTÍNEZ ${ }^{1 *}$, Agustín CORRAL-LUNA ${ }^{1}$, \\ Ana-Luisa RENTERÍA-MONTERRUBIO ${ }^{1}$, M. Eduvigues BURROLA-BARRAZA ${ }^{1}$, Ruth LECHUGA-VALLES ${ }^{1}$, \\ Joel DOMINGUEZ-VIVEROS ${ }^{1}$, Alva-Rocío CASTILLO-GONZÁLEZ ${ }^{2}$, Rogelio SÁNCHEZ-VEGA ${ }^{1}$
}

\begin{abstract}
The aim of this work is to characterize the natural microflora of artisanal Ranchero cheese and to identify Lactococcus isolates. Ten artisanal Ranchero cheese samples made with raw milk were obtained from local producers located in different geographical areas. Aerobic mesophilic, Staphylococci, Psychrophilic, total coliforms, molds, yeast and, lactic acid bacteria (LAB) (Lactococcus, Streptococcus mesophilic and thermophilic, Lactobacillus, Enterococcus, Leuconostoc) were numbered through agar plating. LAB isolates were classified by genus. Then, nineteen randomly selected presumptive Lactococcus isolates were assigned to specie by PCR amplification and DNA sequence. A high number of aerobic mesophilic Staphylococci, Psychrophilic, total coliforms, molds, and yeast were found. Lactococci, mesophilic and thermophilic Streptococci and Lactobacilli were the dominant LAB. Enterococci and Leuconostoc were also present. The isolates were identified as L. lactis subsp. lactis and L. garvieae. And both were found to be the dominant Lactococcus species that could be selected and used in a starter culture. Sanitation deficiencies in the production of artisanal Ranchero cheese were evident, which may translate into being a potential consumers health risk factor.
\end{abstract}

Keywords: Lactococcus; microbiota; artisanal Ranchero cheese.

Practical Application: The knowledge of the microbial quality and LAB involved in the elaboration of artisanal Ranchero cheese would be of great interest, not only to determine its sanitary quality but also to develop an appropriate starter culture that ensures optimum and consistent characteristics of the cheese.

\section{Introduction}

In Mexico, the dairy industry is one of the most important agricultural industries; as such, there is a wide variety of genuine artisan cheeses that represent different regions and their environment of origin. Chihuahua is a Mexican state with one of the highest production of milk and cheeses, where artisanal cheeses are made using traditional production techniques (Servicio de Información Agroalimentaria y Pesquera, 2017a). In 2016, the cheese industry produced 342 thousand tons with a market value of 15 thousand 823 million pesos, the main varieties of cheese produced were: Fresh (17.0\%), Panela (14.0\%) and Double cream (13.0\%) (Servicio de Información Agroalimentaria y Pesquera, 2017b). Because Mexico has a deficit in milk production, it is not considered a cheese exporting country.

The artisanal Ranchero cheese made in Chihuahua is a semipressed dairy product elaborated from raw cow milk, and it is considered as a fresh cheese of bright, milky, and mild flavor, which is consumed within no more than five days after production (Villegas \& Cervantes, 2011).

In cheeses made from raw milk, the contribution of autochthonous fermenting microbiota is prominent (Dagdemir \&
Ozdemir, 2008; Renye et al., 2008; Tunick et al., 2007); therefore, only specific bacterial combinations of strains isolated are used for cheese making. Artisanal Ranchero cheese is made with raw milk and without the addition of starter cultures; therefore, its organoleptic characteristics rely on the lactic microbiota presents in raw milk, which is dependent to the geographical area of production (Beresford et al., 2001). Also, the presence of yeasts and molds develop and enhance the texture and flavor of the cheese (Lavoie et al., 2012).

Currently, one of the challenges presented by the food industry in Mexico is to provide sufficient safe food for its population. In this context, and until now, artisan cheeses have been given little or no importance, so there is little research related to the quality and characterization of the same as well as a null regulatory regulation in practice. In general, the elaboration of cheese with raw milk is not permitted by Mexican health regulations, which dictate that raw milk can be used only if the cheese is consumed 100 days after its production (Norma Oficial Mexicana, 1994). Nevertheless, artisanal Ranchero cheese is still produced with raw milk because this regulation has not been enforced. An alternative to solve this issue is to develop a specific indigenous starter for 
use in the manufacture of artisanal Ranchero cheese. Therefore, it is important to know the microbial communities inherent in these cheeses. This knowledge can prove essential in dealing with product quality features, authenticity assurance, and traceability along the entire production chain.

Although researchers have studied the microbiota of Mexican cheese, mainly fresh cheese, there is still a need to study genuine Mexican handmade cheeses, such as Ranchero cheese because, to date, there is a lack of knowledge about many features of its genuineness and typicity, such as microbiological quality and biodiversity of the lactic microbiota. Hence, the aim of this work was to identify and characterize Lactococcus isolates present in artisanal Ranchero cheese elaborate with raw milk. This could be taken into consideration to select proper strains for a suitable starter culture for the manufacturing of this cheese.

\section{Materials and methods}

Ten traditional Ranchero cheeses made with raw milk were purchased from different local producers located in different geographical areas in the state of Chihuahua, Mexico $(n=10)$. It is known that the microbiological flora of milk changes when the type of food and climate changes. Chihuahua is the largest state of Mexico, it has mountains, plains and deserts, where temperatures and milk production systems vary considerably. Because of this, the ten samples of cheese were purchased from producers located in ten different geographic areas of the state. The cheeses were transported in sterile bags in a container at $4{ }^{\circ} \mathrm{C}$, and they were examined before $24 \mathrm{~h}$ of chilled storage $\left(4^{\circ} \mathrm{C}\right)$.

For microbiological enumeration and isolation, a sample of $10 \mathrm{~g}$ from each cheese was aseptically homogenized in $90 \mathrm{~mL}$ of phosphate buffer and mixed for $2 \mathrm{~min}$ (Stomacher Lab Blender, London, UK). The homogenized sample was serially diluted (1:10) in sterile phosphate-buffered (Norma Oficial Mexicana, 2010). Each dilution was plated onto a specific media by triplicate. Psychrotrophs and aerobic mesophilic microorganisms were plated onto plate count agar (PCA; Oxoid, Basingstoke, U.K.) and incubated at $5{ }^{\circ} \mathrm{C}$ (Psychrotrophs) and $30{ }^{\circ} \mathrm{C}$ (Aerobic mesophilic). M17 agar (Oxoid, Basingstoke, U.K.), containing $1 \%$ lactose $(\mathrm{M} 17 \mathrm{~L})$ at $30^{\circ} \mathrm{C}$ and 45

${ }^{\circ} \mathrm{C}$, for mesophilic and thermophilic streptococci, respectively. M17 agar containing $1 \%$ lactose and ciclohexamida $(100 \mu \mathrm{g} / \mathrm{L})$ (M17LC) at $22^{\circ} \mathrm{C}$ for Lactococcus; Rogosa Sharpe agar (MRS) (Oxoid, Basingstoke, U.K.) at $30^{\circ} \mathrm{C}$ for Lactobacilli; MRS agar containing $500 \mu \mathrm{g} / \mathrm{mL}$ vancomycin (MRSV) at $30^{\circ} \mathrm{C}$ for Leuconostoc; Baird-Parker agar (BP; BD Bioxon, Becton Dickinson and Company, Mex) supplemented with egg yolk tellurite (BD Bioxon, Becton Dickinson and Company, Mex) at $37^{\circ} \mathrm{C}$ for Staphylococcus. Kanamycin Aesculin Azide agar (KAA; Oxoid, Basingstoke, U.K.) at $37^{\circ} \mathrm{C}$ for Enterococcus; potato dextrose agar (PDA; BD Bioxon Becton Dickinson and Company, Mex) acidified with $10 \%$ tartaric acid (Merck, falta lugar) at $25^{\circ} \mathrm{C}$ for molds-yeasts; and violet red bile agar (VRB; Oxoid, Basingstoke, U.K) at $32{ }^{\circ} \mathrm{C}$ for total coliforms. Media were inoculated by spreading $100 \mu \mathrm{L}$ of diluted samples onto the agar, except in the case of the VRB media, which was inoculated by pour plate method $(1000 \mu \mathrm{L})$. All inoculated agar media were incubated anaerobically except PCA, PDA, and VRB media. KAA, VRB, and $\mathrm{BP}$ agars were incubated for $24 \mathrm{~h}$; MRS, MRSV and M17L agars were incubated for $48 \mathrm{~h}$; PCA agar at $30^{\circ} \mathrm{C}$ agar was incubated for $72 \mathrm{~h}$; M17LC and PDA were incubated for five days; PCA agar at $5{ }^{\circ} \mathrm{C}$ was incubated for 12 days (Renye et al., 2008). Numbers of colony-forming units (CFU) were counted on the plates with numbers ranging between 10-200 CFU. After incubation period, plates with 10 to 200 colonies were selected for isolation. Four to six colonies were randomly picked from each plate, except from PDA, VRB, and PCA agar at $5{ }^{\circ} \mathrm{C}$. Colony morphology, gram, and catalase reactions were checked. All gram (+), catalase (-) colonies were streaked out three times on MRS or M17 media for rods and cocci, respectively, to assure purity. The isolates were stored at $-80^{\circ} \mathrm{C}$ in liquid medium $(20 \%$ glycerol (Fermont, Monterrey, Nuevo León, México) and 80\% of MRS or M17 broth (Oxoid, Basingstoke, U.K.) for rods and cocci, respectively) for further analysis.

PCR amplification and DNA sequence analysis were performed on randomly chosen isolates from the most significant genera. Genomic DNA was isolated from $1 \mathrm{~mL}$ of the overnight cultures using the DNeasy ${ }^{\circledR}$ Blood \& Tissue Kit (Qiagen, Hilden, Germany), according to the instructions of manufacturers. The obtained genomic DNA was used as template for PCR with the following oligonucleotides: forward primer G17: 5'GTGAAGTCGTAACAAGG'3 (Pangallo et al., 2008), and reverse primer GplusR: 5'GTGAAGTCGTAACAAGG'3 (Chebeňová-Turcovská et al., 2011) for amplification of 16S rRNA genes. The PCR mixture contained $12.5 \mu \mathrm{L}$ Go Taq ${ }^{\circledR}$ Green Master Mix (Promega Corporation, USA), $1 \mathrm{mM}$ each primer, $250 \mathrm{ng}$ template DNA and HPLC-quality water up to the volume of $25 \mu \mathrm{L}$. The PCR conditions consisted in an initial denaturation at $94^{\circ} \mathrm{C}$ for $5 \mathrm{~min}$, followed by 30 cycles of denaturation at $94^{\circ} \mathrm{C}$ for $1 \mathrm{~min}$, annealing at $55^{\circ} \mathrm{C}$ for $2 \mathrm{~min}$ and polymerization at $72^{\circ} \mathrm{C}$ for $3 \mathrm{~min}$, followed by a final polymerization at $72^{\circ} \mathrm{C}$ for $10 \mathrm{~min}$. The PCR products were purified with the Wizard ${ }^{\circledR} \mathrm{SV}$ Gel and PCR Clean-Up System (Promega Corporation, USA), according to the manufacturer's specifications, and sequenced. Sequencing was performed in the Institute of Biotechnology, UNAM in Cuernavaca, Morelos, Mexico. Sequences were analyzed using Sequencher 5.3 (Gene Codes Corp., Ann Arbor, $\mathrm{MI}$ ) and compared with sequences available in GeneBank using the BLASTn algorithm (Altschul et al., 1997).

A multiple alignment of artisanal cheese clone sequences, identified as $16 \mathrm{~S} \mathrm{rDNA}$, and $16 \mathrm{~S}$ sequences obtained from GenBank database was performed using the PHYLIP (Felsenstein, 1989) and Clustal W 1.6 program (Thompson et al., 1994). In addition to the strains isolated in this study, 16S rRNA gene sequences from five closely related strains were included in the analysis: Lactococcus chunganensis (HM2419.1); Lactococcus raffinolactis (HM241918.1); Lactococcus lactis subsp. lactis (KC768838.1); and Lactococcus garvieae (HM241915.1). A phylogenetic tree was generated using the two parameters of Kimura for genetic distances (Kimura, 1980) and the neighbor-joining method (Saitou \& Nei, 1987) with 1000 replications. To avoid any potential bias introduced as a result of sequence addition, the taxon addition order was randomized in the neighbor joining analysis. 
Microorganisms genera were analyzed using basic statistics: $y=\mu+\varepsilon$, where $\mu=$ general average, and $\varepsilon=$ random error. The significance level used for all statistical analyses was $5 \%$. The analyzes were performed using the statistical package SAS version 9.1.3 (Statistical Analysis System, 2006).

\section{Results}

The microbial logarithmic colony forming units $\left(\log _{10} \mathrm{CFU}\right)$ mean counts for lactic and non lactic microorganisms of artisanal ranchero cheese, are summarized in Tables 1 and 2.

Of the total of 320 isolates obtained, 45 (14.06\%) were lost in the subculturing process, $103(32.18 \%)$ could not be classified as LAB, and 172 (53.75\%) were presumptively identified as

LAB genus, accordingly to its capacity for grow at different temperatures, $\mathrm{NaCl}$ concentrations, and its production of
$\mathrm{CO}_{2}$ from glucose (Cogan et al., 1997). Of the 172 isolates, $73(42.5 \%)$ were recognized as Lactococcus; 72 (41.8\%) shown to be Enterococcus; 14 (8.1\%) were considered as Lactobacillus; six isolates (3.5\%) were Mesophilic Streptococcus; four isolates (2.3\%) Leuconostoc and, three isolates (1.7\%) were thermophilic Streptococcus. Randomly chosen Lactococcus isolates were subject to further identification.

PCR amplification and sequence analysis of $16 \mathrm{~S}$ rDNA were performed on isolates randomly chosen from the Lactococcus genera and compared with sequences in GenBank. From that isolates, 13 (68.4\%) were shown to be Lactococcus lactis subsp. lactis, with a $100 \%$ homology; while six isolates $(26.3 \%)$ were identified as Lactococcus garvieae (five of them with a homology of $99 \%$ ), and the other (5.2\%), with a $95 \%$ homology, as is shown in Table 3.

Table 1. Microbial logarithmic counts (mean \pm SD) of non lactic acid bacteria of artisanal Ranchero cheese.

\begin{tabular}{ccccc}
\hline \multicolumn{5}{c}{ Genera $\left(\log _{10}\right.$ CFU/g) } \\
\hline $\mathrm{Me}$ & $\mathrm{S}$ & Co & M and Y & Ps \\
\hline $7.90 \pm 0.69^{\mathrm{a}}$ & $7.32 \pm 0.73^{\mathrm{ab}}$ & $5.90 \pm 1.06^{\mathrm{b}}$ & $4.12 \pm 1.42^{\mathrm{c}}$ & $6.23 \pm 0.85^{\mathrm{b}}$ \\
\hline
\end{tabular}

Different lowercase letters indicates statistically significant difference between genera $(\mathrm{P}<0.05) . \mathrm{Me}=$ Aerobic mesophiles; $\mathrm{S}=$ Staphylococcus spp; Co $=$ Total coliforms; $\mathrm{M}$ and $\mathrm{Y}=$ Molds and yeast; $\mathrm{Ps}=$ Psychrotrophs.

Table 2. Microbial logarithmic counts (mean \pm SD) of lactic acid bacteria of artisanal Ranchero cheese.

\begin{tabular}{|c|c|c|c|c|c|}
\hline \multicolumn{6}{|c|}{ Genera $\left(\log _{10} \mathrm{CFU} / \mathrm{g}\right)$} \\
\hline$L c$ & $\mathrm{Sm}$ & St & $L b$ & $E$ & Le \\
\hline $8.14 \pm 0.22^{\mathrm{a}}$ & $7.79 \pm 0.65^{\mathrm{a}}$ & $7.65 \pm 0.71^{a}$ & $7.65 \pm 0.55^{\mathrm{a}}$ & $6.30 \pm 1.33^{b}$ & $5.45 \pm 1.47^{c}$ \\
\hline
\end{tabular}

Table 3. Bacterial species identified in artisanal Ranchero cheese.

\begin{tabular}{cccc}
\hline Isolate ID & Taxonomic ID & \% Identity* & GenBank Access Number $^{*}$ \\
\hline 2 & Lactococcus lactis subsp. lactis strain Il1403 & 100 & KC768838.1 \\
7 & Lactococcus lactis subsp. lactis strain Il1403 & 100 & KC768838.1 \\
18 & Lactococcus lactis subsp. lactis strain Il1403 & 100 & KC768838.1 \\
96 & Lactococcus lactis subsp. lactis strain Il1403 & 100 & KC768838.1 \\
107 & Lactococcus lactis subsp. lactis strain Il1403 & 100 & KC768838.1 \\
119 & Lactococcus lactis subsp. lactis strain Il1403 & 100 & KC768838.1 \\
120 & Lactococcus lactis subsp. lactis strain Il1403 & 100 & KC768838.1 \\
124 & Lactococcus lactis subsp. lactis strain Il1403 & 100 & KC768838.1 \\
128 & Lactococcus lactis subsp. lactis strain Il1403 & 100 & KC768838.1 \\
136 & Lactococcus lactis subsp. lactis strain Il1403 & 100 & KC768838.1 \\
137 & Lactococcus lactis subsp. lactis strain Il1403 & 100 & KC768838.1 \\
139 & Lactococcus lactis subsp. lactis strain Il1403 & 100 & KC768838.1 \\
140 & Lactococcus lactis subsp. lactis strain Il1403 & 100 & HM241915.1 \\
101 & Lactococcus garvieae strain LMG 8501 & 99 & HM241915.1 \\
130 & Lactococcus garvieae strain LMG 8501 & 99 & HM241915.1 \\
138 & Lactococcus garvieae strain LMG 8501 & 99 & HM241915.1 \\
152 & Lactococcus garvieae strain LMG 8501 & 99 & HM241915.1 \\
164 & Lactococcus garvieae strain LMG 8501 & 99 & HM241915.1 \\
112 & Lactococcus garvieae strain LMG 8501 & 95 & \\
\end{tabular}

${ }^{\star}$ Percent Identity and Accession Number of closest related species in GeneBank. 


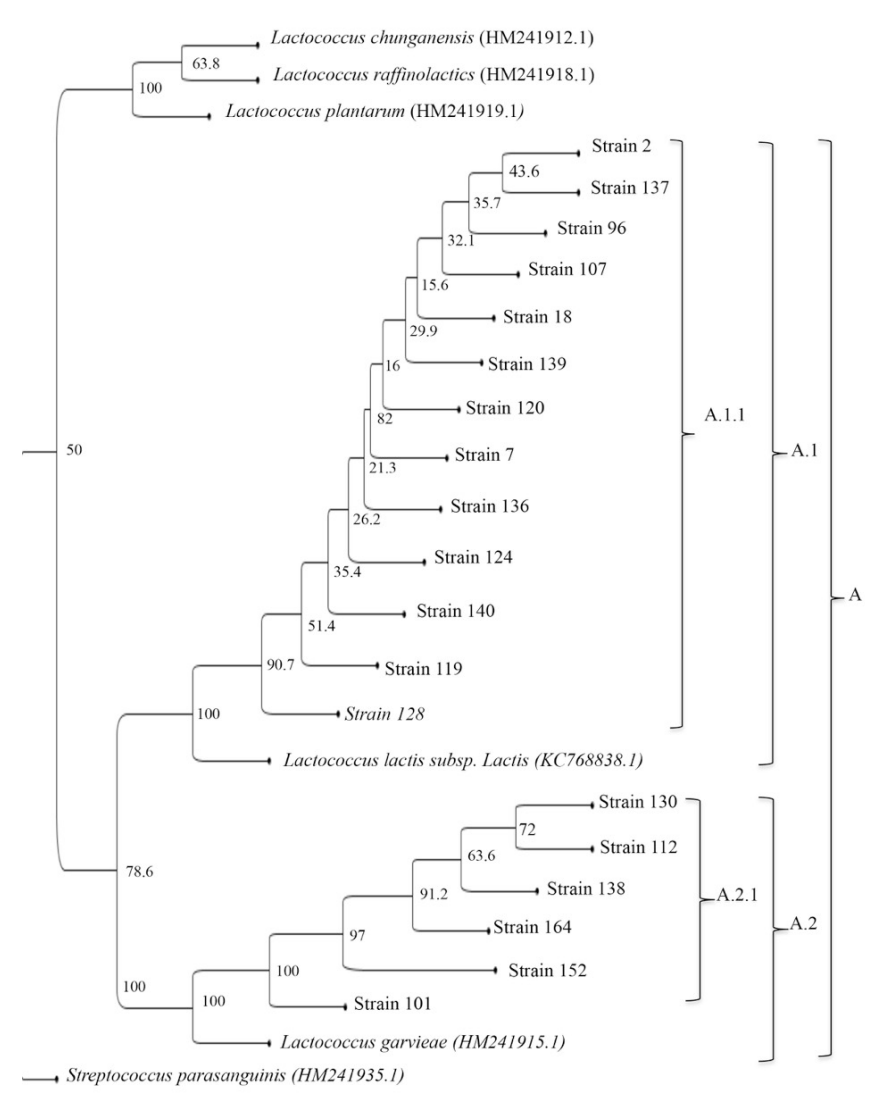

Figure 1. Phylogenetic tree of partial $16 \mathrm{~S}$ rDNA from strains isolated from artisanal Ranchero cheese. The sequences were aligned by the Clustal W program. The distance matrix and phylogenetic tree were calculated with the neighbour-joining algorithms and the method of two parameters of Kimura. Artisanal ranchero cheese $16 \mathrm{Sr}$ rDNA sequences are represented by the strain number. The sequence of Streptococcus parasanguinis served as outgroup sequence. The number of 1000 bootstrap resamplings that support each topological element in the neighbour-joining analysis is indicated.

The phylogenetic analysis classified the strains in a single clade A with a bootstrap value of $78.6 \%$ (Figure 1). Clade A was divided into groups A.1 and A.2. The A.1 group had a bootstrap value of $100.0 \%$ and a sublevel A.1.1 with $90.7 \%$ bootstrap value. All the strains $(2,7,18,96,107,119,120,124$, $128,136,137,139$, and 140) clustered into group A.1.1 were organized monophyletically with Lactococcus lactis subsp. Lactis (KC768838.1). The A.2 group had a bootstrap value of $100.0 \%$ and a sublevel, A.2.1 with $97.0 \%$ bootstrap value. These sublevels contained strains 112, 130, 138, 152, and 164 and all formed a monophyletic group with Lactococcus garvieae (HM241915.1).

\section{Discussion}

The average count of aerobic mesophilic bacteria $\left(7.90 \pm 0.69 \log _{10} \mathrm{CFU} / \mathrm{g}\right)$ was similar to that reported by Renye et al. (2008) and Caro et al. (2013) in fresh cheese (8.02 log CFU/g) and Oaxaca cheese (7.63 log CFU/g), respectively, highlighting that both cheeses were made with raw milk. Mexican legislations do not have a regulation for this parameter (Norma Oficial Mexicana, 1994).

Count of Staphylococcus spp. was, on average, $7.32 \pm 0.73 \log _{10}$ CFU/g. Staphylococcus spp. is considered as microbiological safety only when it exceeds the $4 \log _{10} \mathrm{CFU} / \mathrm{g}$ or when it produces enterotoxins (Yoon et al., 2016). Moreover, Mexican official regulations stipulate a maximum permissible level of $1000 \mathrm{UFC} / \mathrm{g}(3.00 \log 10 \mathrm{CFU} / \mathrm{g})$ in the specific case of $S$. aureus in fresh cheese.

Coliform counts were $5.90 \pm 1.06 \log _{10} \mathrm{CFU} / \mathrm{g}$ on average. Similar values were reported in fresh cheese elaborated with raw milk. Renye et al. (2008) observed counts of $5.90 \mathrm{log} \mathrm{CFU} / \mathrm{g}$; while Torres-Llanez et al. (2006) registered elevated counts not only of total coliforms (around $4.25 \mathrm{log} \mathrm{CFU} / \mathrm{g}$ ) but also fecal coliforms (around $4.5 \log \mathrm{CFU} / \mathrm{g}$ ). The Mexican official regulations established a maximum permissible level for total coliform bacteria of $2.00 \log _{10} \mathrm{CFU} / \mathrm{g}$. High numbers of coliforms could be associated with low hygiene and production process of the artisanal cheese (Solís et al., 2009).

Molds and yeast had an average count of $4.12 \log _{10} \mathrm{CFU} / \mathrm{g}$. Higher values have been found in fresh cheeses elaborated from raw milk (Renye et al., 2008; Torres-Llanez et al., 2006).

Coliforms, molds, and yeast can deteriorate sensorial characteristics and even became a real public health risk. It has been stablished that counts of coliforms, molds, and yeast in artisanal cheeses decrease within the maturation process (Alejo-Martínez et al., 2015). Nonetheless, the artisanal Ranchero cheese is commonly consumed fresh, within five days after processing, representing a risk for the health of the consumers.

As is shown in Table 2, Lactococci was the most abundant $\mathrm{LAB}$ isolated from artisanal ranchero cheese $\left(8.14 \log _{10} \mathrm{CFU} / \mathrm{g}\right)$, followed by mesophilic Streptococci (7.79 $\log _{10} \mathrm{CFU} / \mathrm{g}$ ), thermophilic Streptococci (7.65 $\left.\log _{10} \mathrm{CFU} / \mathrm{g}\right)$, and Lactobacilli microorganisms (7.65 $\log _{10} \mathrm{CFU} / \mathrm{g}$ ), which could indicate that these microorganisms have important roles in odor and flavor characteristics of artisanal and fresh cheeses.

Lactococcus are an important part of the nonstarter microorganisms because they contribute to cheese flavor and texture (Tabak et al., 2012). Lactococcus from dairy products can be generally considered safe because they are consumed daily by humans, and only low incidence of human infections has been reported (Casalta \& Montel, 2008). Lactococcus are also responsible for the initial acidification during the cheese-making process, which determines curd formation and whey expulsion and prevents the growth of undesirable bacteria due of the resulting low $\mathrm{pH}$ concomitant with the production of lactic acid (Karakuş \& Alperden, 1995; Molloy et al., 2011; Renye et al., 2008). Therefore, in the present research, it has been proposed that the isolated Lactococcus could be used as part of starter culture for artisanal Ranchero cheese elaboration, preserving the sensorial characteristics and, according to official regulations, offer an innocuous product to consumers. 
In this study, 19 randomly chosen presumptive Lactococcus isolates were further analyzed. Thirteen $(68.42 \%)$ isolates were identified as L. lactis subsp. lactis and six (31.57\%) as L. garvieae.

The majority of the isolates evaluated were recognized as Lactococcus lactis subsp. Lactis (68.42\%). This LAB is the main component of dairy starter cultures used for the production of diverse fermented products (Cavanagh et al., 2015). However, it is a limited component of the starter cultures to produce cheddar cheese (Wouters et al., 2002). It also may serve as one of the principal acidifying agents for the production of fresh cheese because L. lactis subsp. lactis has been previously identified as part of its natural microbiota (Renye et al., 2008; Torres-Llanez et al., 2006).

Meanwhile, six (31.57\%) isolates were identified as garvieae. It has been isolated from diverse food sources such as fishes, crustaceans, raw milk, and raw milk cheeses (Foschino et al., 2008). At the same time, it has been identified as a fish pathogen and as the etiological agent of mastitis in cows and buffalos (Teixeira et al., 1996). This last may be the reason for its presence in cheeses made with raw milk and the fact that being recognized as a component of the native microflora of dairy products elaborated with raw milk (Fortina et al., 2007; Flórez et al., 2012), such as Ranchero cheese (Renye et al., 2008). Further, it has been linked to human infections (Foschino et al., 2008); however, no association between raw milk cheeses and human infections has been established (Flórez et al., 2012; Foschino et al., 2008).

Even though scarce information is available on phenotypic and biochemical properties of L. garvieae isolated from dairy sources, it has been found that strains from dairy sources are lactose fermenters (Fortina et al., 2007; Teixeira et al., 1996), showing a slow rate of acidificacion, but still comparable with that presented by some Lactococcus isolates (Wouters et al., 2002). And have low proteolitic activity (Fortina et al., 2007), which make their use as starter or adjunct cultures feasible; however, technological characterization should be conducted on the isolates found in this study because some L. garvieae strains are found tetracicline resistance (Fernández et al., 2010).

\section{Conclusions}

Results obtained in the present work showed counts of total coliforms, molds, and yeasts that exceeded the maximum levels allowed by Mexican official regulations; in addition, high counts of aerobic mesophilic bacteria, psychotrophs, and Staphylococcus spp. were observed. These results shows hygienic deficiencies in the production process, which translates into a potential risk factor for consumers' health. Likewise, no differences were found between counts of Lactococcus, Streptococcus mesophilus, Streptococcus thermophilus, and Lactobacillus. Both the GenBank database and the phylogenetic analysis achieved the identification of two Lactococcus species: Lactococcus lactis subsp. lactis and Lactococcus garvieae.

\section{References}

Alejo-Martínez, K., Ortiz-Hernández, M., Recino-Metelin, B. R., González-Cortés, N., \& Jiménez-Vera, R. (2015). Tiempo de maduración y perfil microbiológico del queso de poro artesanal. Revista Iberoamerica de Ciencias, 2(5), 15-24.

Altschul, S. F., Madden, T. L., Schäffer, A. A., Zhang, J., Zhang, Z., Miller, W., \& Lipman, D. J. (1997). Gapped BLAST and PSI-BLAST: a new generation of protein database search programs. Nucleic Acids Research, 25(17), 3389-3402. http://dx.doi.org/10.1093/ nar/25.17.3389. PMid:9254694.

Beresford, T. P., Fitzsimons, N. A., Brennan, N. L., \& Cogan, T. M. (2001). Recent advances in cheese microbiology. International Dairy Journal, 11(4-7), 259-274. http://dx.doi.org/10.1016/S0958-6946(01)00056-5.

Caro, I., Mateo, J., Sandoval, M. H., Soto, S., García-Armesto, M. R., \& Castro, J. M. (2013). Characterization of Oaxaca raw milk cheese microbiota with particular interest in Lactobacillus strains. Journal of Dairy Science, 96(6), 3461-3470. http://dx.doi.org/10.3168/ jds.2012-6103. PMid:23548294.

Casalta, E., \& Montel, M. C. (2008). Safety assessment of dairy microorganisms: the Lactococcus genus. International Journal of Food Microbiology, 126(3), 271-273. http://dx.doi.org/10.1016/j. ijfoodmicro.2007.08.013. PMid:17976847.

Cavanagh, D., Fitzgerald, G. F., \& McAuliffe, O. (2015). From field to fermentation: the origins of Lactococcus lactis and its domestication to the dairy environment. Food Microbiology, 47, 45-61. http://dx.doi. org/10.1016/j.fm.2014.11.001. PMid:25583337.

Chebeňová-Turcovská, V., Ženišová, K., Kuchta, T., Pangallo, D., \& Brežná, B. (2011). Culture-independent detection of microorganisms in traditional Slovakian bryndza cheese. International Journal of Food Microbiology, 150(1), 73-78. http://dx.doi.org/10.1016/j. ijfoodmicro.2011.07.020. PMid:21849217.

Cogan, T. M., Barbosa, M., Beuvier, E., Bianchi-Salvadori, B., Cocconcelli, P. S., Fernandes, I., Gomez, J., Gomez, R., Kalantzopoulos, G., Ledda, A., Medina, M., Rea, M. C., \& Rodriguez, E. (1997). Characterization of the lactic acid bacteria in artisanal dairy products. The Journal of Dairy Research, 64(3), 409-421. http://dx.doi.org/10.1017/ S0022029997002185.

Dagdemir, E., \& Ozdemir, S. (2008). Technological characterization of the natural lactic acid bacteria of artisanal Turkish White Pickled cheese. International Journal of Dairy Technology, 61(2), 133-140. http://dx.doi.org/10.1111/j.1471-0307.2008.00394.x.

Felsenstein, J. P. (1989). Phylogeny inference package (version 3.2). Cladistics, 5, 164-166.

Fernández, E., Alegría, Á., Delgado, S., \& Mayo, B. (2010). Phenotypic, genetic and technological characterization of Lactococcus garvieae strains isolated from a raw milk cheese. International Dairy Journal, 20(3), 142-148. http://dx.doi.org/10.1016/j.idairyj.2009.11.004.

Flórez, A. B., Reimundo, P., Delgado, S., Fernández, E., Alegría, A., Guijarro, J. A., \& Mayo, B. (2012). Genome sequence of Lactococcus garvieae IPLA 31405, a bacteriocin-producing, tetracycline-resistant strain isolated from a raw-milk cheese. Journal of Bacteriology, 194(18), 5118-5119. http://dx.doi.org/10.1128/JB.00975-12. PMid:22933752.

Fortina, M. G., Ricci, G., Foschino, R., Picozzi, C., Dolci, P., Zeppa, G., Cocolin, L., \& Manachini, P. L. (2007). Phenotypic typing, technological properties and safety aspects of Lactococcus garvieae strains from dairy environments. Journal of Applied Microbiology, 103(2), 445-453. http://dx.doi.org/10.1111/j.1365-2672.2006.03265.x. PMid:17650205.

Foschino, R., Nucera, D., Volponi, G., Picozzi, C., Ortoffi, M., \& Bottero, M. T. (2008). Comparison of Lactococcus garvieae strains isolated in northern Italy from dairy products and fishes through molecular typing. Journal of Applied Microbiology, 105(3), 652-662. http:// dx.doi.org/10.1111/j.1365-2672.2008.03780.x. PMid:18341557. 
Karakuş, M., \& Alperden, I. (1995). Effect of starter composed of various species of lactic bacteria on quality and ripening of turkish white pickled cheese. Lebensmittel-Wissenschaft + Technologie, 28(4), 404409. http://dx.doi.org/10.1016/0023-6438(95)90024-1.

Kimura, M. (1980). A simple method for estimating evolutionary rates of base substitutions through comparative studies of nucleotide sequences. Journal of Molecular Evolution, 16(2), 111-120. http:// dx.doi.org/10.1007/BF01731581. PMid:7463489.

Lavoie, K., Touchette, M., St-Gelais, D., \& Labrie, S. (2012). Characterization of the fungal microflora in raw milk and specialty cheeses of the province of Quebec. Dairy Science \& Technology, 92(5), 455-468. http://dx.doi.org/10.1007/s13594-011-0051-4. PMid:23125908.

Molloy, E. M., Hill, C., Cotter, P. D., \& Ross, R. P. (2011). Bacteriocins. In J. W. Fuquay, P. F. Fox \& P. L. H. McSweeney (Eds.), Encyclopedia of dairy sciences (2nd ed., pp. 420-429). London: Elsevier Academic Press. http://dx.doi.org/10.1016/B978-0-12-374407-4.00049-2.

Norma Oficial Mexicana - NOM. (1994). NOM-121-SSA1-1994: bienes y servicios: quesos: frescos, madurados y procesados: especificaciones sanitarias. México: Diario Oficial.

Norma Oficial Mexicana - NOM. (2010). NOM-243-SSA1-2010: productos y servicios: leche, fórmula láctea, producto lácteo combinado y derivados lácteos: disposiciones y especificaciones sanitarias: métodos de prueba. México: Diario Oficial.

Pangallo, D., Drahovska, H., Harichova, J., Karelova, E., Chovanova, K., Aradska, J., Ferianc, P., Turna, J., \& Timko, J. (2008). Evaluation of different PCR-based approaches for the identification and typing of environmental enterococci. Antonie van Leeuwenhoek, 93(1-2), 193203. http://dx.doi.org/10.1007/s10482-007-9193-z. PMid:17929191.

Renye, J. A., Somkuti, G. A., Vallejo-Cordoba, B., Van Hekken, D. L., \& Gonzalez-Cordova, A. F. (2008). Characterization of the microflora isolated from Queso Fresco made from raw and pasteurized milk. Journal of Food Safety, 28(1), 59-75. http://dx.doi.org/10.1111/j.17454565.2007.00095.x.

Saitou, N., \& Nei, M. (1987). The neighbor-joining method: a new method for reconstructing phylogenetic trees. Molecular Biology and Evolution, 4(4), 406-425. PMid:3447015.

Servicio de Información Agroalimentaria y Pesquera - SIAP, Secretaria de Agricultura, Ganadería, Desarrollo Rural, Pesca y Alimentación. (2017a). Boletín de la leche. México: SIAP. Retrieved from http://infosiap. siap.gob.mx/opt/boletlech/Brochure\%20leche_septiembre2017.pdf

Servicio de Información Agroalimentaria y Pesquera - SIAP, Secretaria de Agricultura, Ganadería, Desarrollo Rural, Pesca y Alimentación. (2017b). Panorama de la leche en México. México: SIAP. Retrieved from http://infosiap.siap.gob.mx/opt/boletlech/Brochure $\% 20$ leche_septiembre2017.pdf

Solís, A., Yong, G., Estrada, J., \& Castelán, O. (2009). Retos de la producción artesanal de los quesos mexicanos para ingresar al concepto limpio, verde y ético. Agrociencia, 13(3), 88.

Statistical Analysis System - SAS. (2006). Version 9.1.3 for Windows. Cary: SAS Institute Inc.

Tabak, S., Maghnia, D., \& Bensoltane, A. (2012). The antagonistic activity of the lactic acid bacteria (Streptococcus thermophilus, Bifidobacterium bifidum and Lactobacillus bulgaricus) against Helicobacter pylori responsible for the gastroduodenals diseases. Journal of Agricultural Science and Technology, 2(5A), 709-715.

Teixeira, L. M., Merquior, V. L. C., Vianni, M. D. C. E., Carvalho, M. D. G. S., Fracalanzza, S. E. L., Steigerwalt, A. G., Brenner, D. J., \& Facklam, R. R. (1996). Phenotypic and genotypic characterization of atypical Lactococcus garvieae strains isolated from water buffalos with subclinical mastitis and confirmation of L. garvieae as a senior subjective synonym of Enterococcus seriolicida. International Journal of Systematic Bacteriology, 46(3), 664-668. http://dx.doi. org/10.1099/00207713-46-3-664. PMid:8782673.

Thompson, J. D., Higgins, D. G., \& Gibson, T. J. (1994). Improving the sensitivity of progressive multiple sequence alignment through sequence weighting, position-specific gap penalties and weight matrix choice. Nucleic Acids Research, 22(22), 4673-4680. http:// dx.doi.org/10.1093/nar/22.22.4673. PMid:7984417.

Torres-Llanez, M. J., Vallejo-Cordoba, B., Díaz-Cinco, M. E., MazorraManzano, M. A., \& González-Córdova, A. F. (2006). Characterization of the natural microflora of artisanal Mexican Fresco cheese. Food Control, 17(9), 683-690. http://dx.doi.org/10.1016/j.foodcont.2005.04.004.

Tunick, M. H., Van Hekken, D. L., Call, J., Molina-Corral, F. J., \& Gardea, A. A. (2007). Queso Chihuahua: effects of seasonality of cheesemilk on rheology. International Journal of Dairy Technology, 60(1), 13-21. http://dx.doi.org/10.1111/j.1471-0307.2007.00295.x.

Villegas, A., \& Cervantes, F. (2011). La genuinidad y tipicidad en la revalorización de los quesos artesanales mexicanos. Estudios Sociales, 19(38), 146-164.

Wouters, J. T., Ayad, E. H., Hugenholtz, J., \& Smit, G. (2002). Microbes from raw milk for fermented dairy products. International Dairy Journal, 12(2-3), 91-109. http://dx.doi.org/10.1016/S0958-6946(01)00151-0.

Yoon, Y., Lee, S., \& Choi, K.-H. (2016). Microbial benefits and risks of raw milk cheese. Food Control, 63, 201-215. http://dx.doi.org/10.1016/j. foodcont.2015.11.013. 